\title{
PrivaCy, POWER, AND HuMiLIATION AT WORK: \\ RE-EXAMINING APPEARANCE REgULATION AS AN INVASION OF PRIVACY
}

\section{Catherine L. Fisk ${ }^{*}$}

It is only shallow people who do not judge by appearances. The true mystery of the world is the visible, not the invisible. ${ }^{I}$

For several decades, civil libertarians on the bench, at the bar, and in the academy have argued that privacy - whether as a constitutional or statutory right or as protected by the common law - should be understood as two separate concepts: freedom from intrusion and protection for autonomy. As many have observed, they are not unrelated: both are about limiting exertions of government or institutional power for the sake of protecting the boundary between the self and society and, ultimately, the vitality of both. The relationship between privacy and autonomy is quite plain in the workplace. We experience some workplace rules that deny privacy or autonomy as invasions of the self. Perhaps nowhere is the invasion more keenly felt than when an employer demands, under penalty of forfeiting one's livelihood, that one dress or alter one's physical appearance in a way that one finds offensive, degrading, inappropriate, or alien.

Clothes and appearance are constitutive of how we see and feel about ourselves and how we construct ourselves for the rest of the world to see. Most people give careful

\footnotetext{
* Professor of Law, Duke University School of Law. Thanks to Erwin Chemerinsky, Mitu Gulati, and Erica Williamson for conversations that deepened my thinking on this topic. Williamson's research for her own work on this topic made my paper possible; her conversations with me made it fun. Since they all disagree with some of what I say, I owe it to them to remind readers that responsibility for errors and anathemas is my own. Thanks also to the participants in the Louisiana Law Review symposium "Examining Privacy in the Workplace."

${ }^{1}$ OSCAR Wilde, THE Picture OF DORIAN GRAY 22 (1981 ed.) (1891).
} 
thought to how they dress as a part of defining who they are. We dress to establish an identity and to fit in with some subculture while rejecting others. (Green hair or brown? Dreads or straighteners? Make-up or none? Brooks Brothers suits or Tshirts and jeans? Miniskirt and stilettos or jeans and Birkenstocks?) Dressing does more than "fit[] the dresser into one of the available, intelligible categories of people," it is "performative in the sense that it does something in the world, rather than just representing an 'interior.",2 That is, people create culture through their actions, including dress. Even those who profess to attend little to their appearance make disregard of appearance part of their definition of self; they see themselves as free of vanity and superficiality, and they participate in the creation of a subculture that rejects obvious attention to appearance.

Dress not only defines us, it affects how we feel on a daily basis. People who like to dress up often say it makes them feel more handsome, dignified, and powerful. People who loathe dressing up say it makes them feel bound up, stilted, and oppressed. Conventions of appearance for women and men, and for racial, ethnic, and religious groups express and observe political and spiritual commitments that affect people at a deep psychological level. Anyone who thinks that appearance regulation is trivial just isn't thinking hard enough. ${ }^{3}$

In this essay, I argue that the legal framework of autonomy privacy is a necessary supplement to the discrimination analysis that has dominated legal thinking for thirty-five years of challenges to workplace appearance requirements. ${ }^{4}$ Appearance is an important

\footnotetext{
${ }^{2}$ DunCan Kennedy, SeXy Dressing, EtC. 186 (1993).

${ }^{3}$ People do sometimes insist that dress codes are too trivial to be worthy either of legal regulation or of much attention at all. Examples from judicial opinions are collected and the assertion is debunked in Katharine T. Bartlett, Only Girls Wear Barrettes: Dress and Appearance Standards, Community Norms, and Workplace Equality, 92 MicH. L. REV. 2541, 2556-59 (1994).

${ }^{4} \mathrm{I}$ am not the first to see the values of privacy as well as equality at state in legal protection for some degree of freedom of dress in the workplace. See Matthew W. Finkin, Employee Privacy, American
} 
aspect of the way we perform our racial, gender and other identities, dress codes often discriminate on the basis of race, religion, gender, ethnicity, sexual orientation, age or disability, and when they do they should be illegal. ${ }^{5}$ Nevertheless, I believe it is important to recognize that some appearance requirements should be legally suspect even when they do not discriminate on the basis of a protected status. On that basis I will argue for a fundamental re-examination of the legal regulation of workplace appearance codes. While the re-examination may be fundamental, the permissibility of many appearance codes would not necessarily change radically: some will be illegal, many will be legal. I argue for a change of emphasis rather than a revolution in outcomes.

A privacy analysis, in contrast to a discrimination analysis, is a legal theory that is available to anyone who is significantly oppressed by an unreasonable workplace dress code. Privacy analysis may thus be more resistant to charges of special treatment and the backlash that such charges can generate. ${ }^{6}$ From the employer's standpoint, privacy analysis allows more flexibility and nuance in distinguishing appearance regulations that are legal from those that are not. It might, for example, preserve the ability of an employer to require some dress conventions, including some that may reflect gender, religious, and other norms, while ruling out others. A law firm might be able to require coats and ties for men but not skirts for women, even though both are explicitly gender-

\footnotetext{
Values, and the Law, 72 CHI.-KenT L. REV. 221, 251-53 (1996); Annabelle Lever, What's Wrong with that Beard? Privacy and Equality in the Workplace: The Struggle Over Dress and Grooming Codes (unpublished manuscript on file with the author). Nevertheless, as the citations infra in note _ suggest, the dominant legal analysis of workplace grooming requirements has been through the lens of antidiscrimination rather than privacy.

${ }^{5}$ On workplace discrimination and the performance of racial identity, see Devon W. Carbado \& Mitu Gulati, Working Identity, 85 CORNELL L. REV. 1259 (2000).

${ }^{6}$ Arguing that an approach to rights that benefits all, rather than is perceived as special treatment for some, see Derrick A. Bell, Jr., Comment, Brown v. Board of Education and the Interest-Convergence Dilemma, 93 Harv. L. Rev. 518, 523 (1980); Pauline T. Kim, Genetic Discrimination, Genetic Privacy: Rethinking Employee Protections for a Brave New Workplace, 96 NORTHWESTERN L. REV. 1497 (2002).
} 
based and neither is a bona fide occupational qualification, because a court might conclude that the autonomy infringement might be greater for the women and the justification for appealing to the preferences of the employer or customers for men to look professional is greater than for women to look sexy. A privacy analysis would help courts distinguish between dress codes that humiliate and those that do not, as well as help a court understand that a dress code can be generally valid but cannot be enforced against a particular employee who might find a particular dress requirement exceptionally humiliating or offensive.

Wholly apart from the effects of a privacy analysis on the outcome of litigation, I think it will also prompt a more thoughtful analysis by firms of whether or how they should attempt formally to regulate employee appearance and how to handle the employee who objects. Employment law should attend not only to how rules would be applied in litigation but also, perhaps even most importantly, to how rules affect voluntary compliance. ${ }^{7}$ A privacy analysis will prompt an employer to consider the strength of its justification for its policy, the degree of humiliation it will affect on particular workers, and whether the harm is necessary to achieve the benefit. A discrimination analysis, by contrast, invites an employer to adopt even a silly appearance regulation (e.g., women must wear make-up and nail polish) if the employer can convince itself that the regulation is not sex discrimination because it equally burdens men or because only certain women will object. Privacy analysis will thus better identify and

\footnotetext{
${ }^{7}$ One could argue, for example, that the major achievement of the Americans With Disabilities Act, 42 U.S.C. 12101, et seq. is not reflected in the results of litigation, where plaintiffs lose overwhelmingly and where the law has been steadily narrowed by judicial interpretation, see, e.g., Ruth Colker, Winning and Losing Under the Americans With Disabilities Act, 62 OHIO ST. L.J. 239 (2001), but through voluntary compliance that changed employer assumptions about what they can and should do with disabled applicants and employees.
} 
accommodate the employer's interest in the appearance of its workforce with interests of various employees in being free from humiliating workplace requirements.

\section{Dress Codes, Status and Power}

A few months ago, I received a request for legal advice from an employee of a school that had recently instituted a dress code for all staff. The new rules required male staff to wear khaki slacks and a collared shirt. The man, an electrician who often worked outdoors and in un-air-conditioned spaces, said he could not wear light colored clothes because he has a physical condition that causes him to perspire profusely. As he explained it, "If I have to wear khaki pants, inside of an hour I'll look like I wet myself. The students will laugh, and I'm just not willing to be humiliated." I suggested that he get medical documentation of his condition and ask his employer to make an exception to allow him to wear dark-colored clothes. The man called me back a week later and said that his employer refused to make an exception. I thought about suggesting litigation except I couldn't find a legal theory - his perspiration condition is probably not a disability (because excessive perspiring probably does not interfere with a major life activity $^{8}$ ); firing him wasn't a breach of contract (he was an at will employee); it was hard to identify a public policy that was offended by a khaki pants uniform; and the dress code was not adopted or maintained for the purpose of intentionally inflicting emotional distress. The man decided to resign rather than to be humiliated by complying with the dress code or by having a confrontation over refusing to comply.

\footnotetext{
${ }^{8}$ The Americans with Disabilities Act defines a disability as a "physical or mental impairment that substantially limits one or more of the major life activities of [an] individual." 42 U.S.C. 12102 (2)(A).
} 
I was at first stunned that the school district would reject what I considered such a minor and reasonable request and would let a long-term employee go over it. But when I thought about it, I realized that the school officials interpreted his request for an exemption as a major challenge to their authority. And, as I thought about why they thought so much was at stake over khaki as opposed to black chino pants, I realized why this wasn't trivial to them. If they made an exception for one employee, they must have feared being inundated with requests for exceptions for employees who didn't want to buy a new wardrobe. They may have worried that other employees would suspect favoritism as they wondered why he was treated differently. From the employer's perspective, allowing one employee an alternative to the dress code, even a dress code as arbitrary (but as conventional) as one that required khaki-colored pants instead of darkcolored ones, would risk not only the dress code but also the employer's reputation for even-handedness. An employer that announces a mandatory dress code and then cannot enforce it loses control over the workplace in a way that it would perceive as quite serious. It would upset the power structure. Soon, the school officials might have feared, they would lose control over their "right" (or at least their ability) to demand that employees dress professionally and model appropriate behavior for students. Needless to say, schools are acutely aware of the importance of maintaining discipline. From my own grim memories of the barely controlled chaos in my junior high, I'm not entirely unsympathetic to the general sentiment, much as I thought the employer's desire to win this particular power struggle was silly and misguided.

The experience of the man who could not wear khaki pants also offers perspective on why the matter of dress codes ought not be left to the negotiations of employer and 
employee. The very definition of a dress code is one that must be applied to all employees of a certain category. A khaki pants requirement is probably unobjectionable to many, and thus I imagine it would rather difficult for the man I spoke with to persuade his co-workers to join his cause. If they were going to stand up and fight over working conditions, I suspect they'd rather fight for a longer lunch break or higher pay or a better student-teacher ratio. So my guy had no effective voice, his only "choice" was to quit. That is the plight faced by any minority - a Sikh who wishes to wear a turban, a woman who really detests make-up. Protecting the minority from having to choose between a job and something really important is what employment law is all about.

Another window on the importance of power and autonomy, as well as gender conformity, in workplace appearance regulation is Jespersen v. Harrah's Operating Company, which is the case of Darlene Jespersen, who had been a bartender in the sports bar at Harrah's casino in Reno for many years until she was fired after refusing accept the casino's new requirement that women wear make-up and nail polish. ${ }^{9}$ She had not worn make-up to work for years and Harrah's had tolerated it. Moreover, what actually prompted the firing was not that Jespersen came to work one day without make-up, but rather that her supervisor provoked a show-down over Jespersen's refusal to sign a statement promising to comply with the new appearance policy. The policy, which Harrah's called a "Personal Best Program," was adopted as part of a "Beverage Department Image Transformation.” Harrah's hired a make-up expert to give each employee a make-over and then had a photographer take a post-make-over photograph of

\footnotetext{
9392 F.3d 1076 (9th Cir. 2004), reh'g en banc granted, 409 F.3d 1065 (2005). I rely on Devon Carbado, Mitu Gulati, and Gowri Ramachandran, The Jespersen Story: Makeup and Women at Work, in JOEL W. FRIEDMAN, ED., EMPLOYMENT DISCRIMINATION STORIES (2006) for the facts in this paragraph; all quotations are to their chapter.
} 
each employee. Harrah's instructed supervisors to use the photograph as an "appearance measurement tool": that is, the supervisor was empowered and encouraged to compare an employee to his or her photograph on a daily basis to see whether he or she measured up. The appearance code required females to wear specific types of make-up: foundation, blush, mascara, and lipstick. Other requirements included "teased, curled, or styled" hair and colored nail polish. She was fired because she challenged the power of the company to change her appearance. Although much of the writing on Jespersen has focused on gender conformity, I think that power and humiliation are as important to understanding the case as is gender. I imagine that a number of women who have no objection to wearing make-up might have been offended by and rebelled against the intrusiveness and demeaning nature of the Harrah's policy.

Because Title VII offered the only available claim, Jespersen's lawyers had very good strategic reasons to play up the gender identity issue and to play down the power struggle, but in doing so they had to omit a crucial part of the story. Part of what Harrah's was trying to do to Jespersen was to feminize and sexualize her, but part of it was simply trying to control her. Put another way, if I were in her situation I'd be offended by the "Personal Best" requirement even though I personally have no objection to styling my hair and wearing make-up. The Harrah's policy should be illegal not only because or to the extent that it forces women to perform a particular version of a feminine gender identity, it should be illegal even if every female Harrah's employee is comfortable with a version of femininity that involves wearing make-up and nail polish, simply because it removes their autonomy to choose. Considering the case only through the lens of sex discrimination ignores the concerns of all employees, male and female, 
who find unnecessarily demeaning the use of the "Personal Best" photograph as a measurement device, and the notion that your supervisor is empowered to scrutinize the minute details of your appearance on a daily basis, comparing you to a photograph, and reprimanding you if on a particular day your supervisor decides you just don't look enough like an idealized image of yourself all done up.

Another perspective on the importance of power and humiliation in appearance regulation is offered by the cases involving people who are disciplined for covering their heads according to the dictates of their religion. It is not hard to see that a dress code that prohibits turbans, yarmulkes, or headscarves disparately affects certain religions. But many people believe that the discrimination should be permissible because people ought to assimilate culturally. The skepticism about these claims often comes from a notion that law should not require employers to accommodate unconventional habits of dress regardless of an employee's reason for choosing them. If the Air Force can prohibit all people from wearing hats indoors or at night, why should a Jew get a special exception? ${ }^{10}$ A privacy analysis helps us see why the Air Force's requirement really does harm a Jewish man or a Sikh in a profound sense that is not captured simply by thinking about when or whether people should be treated equally or differently. Privacy refocuses our attention away from whether Jews get a special exception from an appearance requirement that many may find reasonable and toward the ways in which some applications of appearance requirements that are at most annoying or silly to some and would to others be so offensive that he would rather be discharged or quit rather than comply.

\footnotetext{
${ }^{10}$ The Supreme Court held that a Jewish officer was not entitled to an exemption from the no-hats rule in Goldman v. Weinberger, 475 U.S. 503 (1986).
} 
From perspective of power and humiliation that privacy analysis invites us to consider, Price Waterhouse v. Hopkins might read quite differently than it customarily is. ${ }^{11}$ Ann Hopkins, a candidate for partnership in the Price Waterhouse accounting firm, was passed over for partnership and was advised that her chances for reconsideration would improve if she wore make-up, styled her hair, and wore jewelry. The Court held that Hopkins was a victim of illegal sex stereotyping. ${ }^{12}$ Of course it is a case about discrimination. But the use of Ann Hopkins' appearance as a reason to deny her partnership both reflects and exacerbates her humiliating lack of status in the workplace as well as the stereotyping that kept her from being perceived as successful. Most people would probably encourage women and men at an accounting firm to dress conventionally, which might include not looking too butch or too feminine (in the case of women), or too ethnic (in the case of racial or ethnic minorities) or too sloppy or unprofessional (in the case of white men). Price Waterhouse partners might say, in their own defense: "Look, there's an appearance code here for everybody, and a man who regularly failed to dress conventionally for work - by showing up without a tie or in sweatpants or unshaven - would also not be welcomed into the partnership either, so we're not discriminating. It's just that somebody came out and said it to her." But what you see reading between the lines of the decision is that men who broke norms of appearance were probably quietly reminded to spiff up a bit, whereas Ann Hopkins was called on the carpet (and fired). The firm breached the norm that appearance codes are not spelled out in detail and enforced by adverse job action against professionals. The firm underscored Hopkins' humiliating lack of status by acting like the headmistress of

\footnotetext{
11490 U.S. 228 (1989).

${ }^{12} I d$. at 235.
} 
my parochial high school who used to feel entitled to remark on which girls wore their uniform skirts too short and who needed to polish her saddle shoes. In short, appearance codes are about power as well as about stereotyping, and I think we miss much of the nuance when we focus only on one element.

Let me now move from the particularity of these four cases to a general theoretical framework for considering workplace appearance regulation. Most accounts of dress codes in legal scholarship have focused on the ways that they enable both employers and employees to do what economists refer to as "screening" and "signaling." ${ }^{, 13}$ Screening is the information economics term for devices that people use to filter out the desirable from the undesirable in the market. Signaling refers to the way that buyers and sellers in a market reveal valuable but nonobvious information about themselves. In the conventional account, dress is a way of signaling certain qualities (professionalism, religious devotion, attitudes toward sex) and dress regulation is a way that employers use these signals both to screen potential employees for certain traits and to enable customers or other potential trading partners to screen out some business establishments in favor of others when they seek a good or service in the marketplace. ${ }^{14} \mathrm{I}$ do not disagree that dress codes perform these functions. I want to suggest, however, that appearance codes play other roles as well.

\footnotetext{
${ }^{13}$ The literature discussing appearance requirements is voluminous. Among the leading or recent articles are Kimberly A. Yuracko, Trait Discrimination as Sex Discrimination: An Argument Against Neutrality, 83 TEX. L. Rev. 167, 168 (2004); Kimberly A. Yuracko, Private Nurses and Playboy Bunnies: Explaining Permissible Sex Discrimination, 92 CALIF. L. Rev. 147 (2004); Robert Post, Predudicial Appearances: The Logic of American Antidiscrimination Law, 88 CAL. L. REV. 1 (2000); Mary Anne Case, Disaggregating Gender from Sex and Sexual Orientation: The Effeminate Man in the Law and Feminist Jurisprudence, 105 YALE L.J. 1 (1995); Katharine Bartlett, Only Girls Wear Barrettes: Dress and Appearance Standards, Community Norms, and Workplace Equality, 92 Mich. L. REV. 2541, 2553-55 (1994); Karl E. Klare, Power/Dressing: Regulation of Employee Appearance, 26 NEw ENG. L. REv. 1395, 1428 (1992); Mary Wisner, Gender Specific Clothing Regulation: A Study in Patriarchy, 5 HARV. WOMEN'S L.J. 73, 74 (1982).

${ }^{14}$ See Carbado \& Gulati, Working Identity, supra note
} 
Sociologists, anthropologists, and high-school kids know that appearance is a mark of status, or, more accurately, what sociologist Erving Goffman called "social identity": the mix of personal and social attributes through which every society categorizes people. ${ }^{15}$ As Goffman long ago observed, "first appearances are likely to enable us to anticipate [a stranger's] category and attributes," and we use our expectations based on appearances to make quick judgments about people. "We lean on these anticipations we have, transforming them into normative expectations, into righteously presented demands." 16 A supervisor might think is he demanding adherence to certain norms of appearance because the expected method of dress connotes a higher or distinct status (as when a firm or a court demands that men wear suits and ties). When an employee refuses to accede to conventions of dress in a particular workplace, however, she asserts her status as being beyond the power of the employer to demand conformity. When an employer insists upon conformity, the struggle quickly becomes as much about maintaining discipline and controlling deviance as it is about enforcing particular norms of race, gender, or religion. Thus, although a mode of dress chosen, even under the influence of social norms, can be a marker of an individual's status, the same mode of dress explicitly compelled becomes a marker of the employer's higher status and the employee's subordination. In this analysis, we see that appearance codes do more than screen and signal, they are a battleground of social power.

To see why, consider some examples that have recently been in the news. When David Stern, the commissioner of the NBA, recently announced that professional basketball players should dress like businessmen rather than like rappers when appearing

\footnotetext{
${ }^{15}$ See, e.g., ERving Goffman, Stigma: Notes on the MANAGEMENT OF Spoiled IdEntity (1963).

${ }^{16} \mathrm{Id}$. at 2.
} 
in public, ${ }^{17}$ and when George Steinbrenner made Johnny Damon cut his hair as a condition of signing him to the Yankees, ${ }^{18}$ the heart of the offense (if there is an offense) is not that the NBA and the Yankees are discriminating on the basis of race or gender; the offense (if there is one) is that they are trying to make players project an image that some players don't want to project. There may be, especially in the case of the NBA, an aspect of the dispute that is about discrimination in the way that people perform racial or gender identity, but there is in my view a larger sense in which the disputes aren't about discrimination, they are about the power to project an image.

In the case of the NBA players, one could argue that the chosen attire of the players connotes some aspect of urban black subculture, but it takes a bit of essentializing to argue that business dress is somehow "white." Moreover, some of the attire that the NBA sought to eradicate in public appearances is less "black" than it is urban countercultural, as some young men of all races dress that way. Many supporters and some critics of the NBA dress code were uncomfortable saying that the problem was its effort to make players look less "black" because it says that professional dress is "white." To me, what is at least as important as whether the appearance code is racial stereotyping is that it is an effort to control how the players express themselves through their dress. The NBA is big business for big business. NBA players, when they're not entertaining

\footnotetext{
${ }^{17}$ The NBA dress code for off-court wear requires players to wear "business or conservative attire" (collared shirts, closed-toe shoes, sport coats, and no ostentatious jewelry) while traveling, on the bench during a game and not in uniform, making official appearances, or conducting league business. http://en.wikipedia.org/wiki/NBA_dress_code. All seem to agree that the purpose of the code was to avoid players' appearance evoking "hip hop culture," or what one newspaper columnist characterized as players "looking like recruiting officers for the Crips and the Bloods." Frank Deford, Suiting Up: NBA Dress Code Draws Criticism from Many Corners, Sports Illustrated, Oct 26, 2005, available at www.sportsillustrated.cnn.com (quoting Phil Muchnick of The New York Post). The NBA also recently has begun enforcing a rule regulating players' on-court wear, requiring shorts to be one inch above the knee, again for the same stated purpose: to avoid players looking too hip-hop. See Selena Roberts, NBA Dress Code Confuses the Long and Short of It, NY TIMES, Dec. 6, 2005.

${ }^{18} \mathrm{http} / / / \mathrm{en}$.wikipedia.org/wiki/Beard\#Sport ("Under owner George Steinbrenner, the New York Yankees baseball team has a strict dress code that forbids long hair and facial hair below the lip.")
} 
business people watching a game from their luxury boxes, are often touted as role models for kids; they promote reading, hard work, etc. Neither role is consistent, at least in the eyes of some NBA officials, with looking like rebellious teens because the image connoted by certain clothing is not "blackness," it is (to some people's view) criminality and a lack of respect for education. So the NBA insisted that the players project a conventional business image rather than an urban renegade subculture image. What bothers me is not the racial connotations of the dress code but that it puts the NBA in the role of a judgmental parent ("You're not going out of the house dressed like that") and the players in the position of recalcitrant teens.

Damon's hair is an even better case for re-considering dress codes as autonomy infringements rather than status discrimination. Damon's long hair and beard may have been flamboyant and unconventional, but it wasn't a marker of a protected status (people said it made him look like Jesus, but no one claims that Steinbrenner was discriminating against Christians in requiring short hair and no beards). ${ }^{19}$ It had become a marker of his status as a marquee player, as someone so recognizable that he could be easily spotted even by those ignorant about baseball when he played himself in a movie. ${ }^{20}$ Insisting on adherence to the dress code says to the world, "you're my player now and I can make you wear your hair in any way I please.” That professional athletes are fantastically well compensated does not make the regulation of their appearance any less an infringement on their autonomy; it only means that they are paid well for enduring it.

\footnotetext{
${ }^{19} \mathrm{See}$ http://www.boston.com/sports/baseball/redsox/articles/2004/02/26/hairs_johnny_damon_shocks ("heads turned as Damon, fully bearded, with his brown hair flowing to his shoulders, submitted one of the best impersonations of Jesus of Nazareth this side of "The Passion of the Christ.")

${ }^{20}$ Damon's distinctive appearance helped to make him a minor character in the film about the Boston Red Sox' World Series winning season, Fever Pitch.
} 
Finally, to see why the appearance regulations sought to be imposed on these athletes was as much about power as about discrimination, consider the circumstances in which an employer feels empowered to articulate and enforce an explicit dress code. Dress codes are usually defended by reference to the employer's "right" or "power" to present the corporate image of its choice. As professor of consumer behavior put it, "to have somebody really out of context destroys the illusion" that a company chooses to create for its public. ${ }^{21}$ But many firms either don't explicitly articulate a dress code or don't enforce it because to do so would be contrary to the norms of the occupation or the firm. Most universities, for example, do not maintain dress codes for faculty. High status jobs are more likely to leave dress codes quite vague ("business attire" or "casual Fridays") and not to call nonconformists onto the carpet in an explicit way.

When the norms of appearance autonomy are violated in high status jobs, the offense cannot be captured solely through the rubric of unequal treatment. If the dean of my law school came to my office to ask me to dress more formally to teach, the offense would not be sex discrimination, even if business clothes are different for men and women (unless of course she confronted only women and allowed men to dress casually). The offense to me would be the dean asserting the power to tell me what image I am to project. Though I never wear jeans to teach, my immediate instinct would be to wear nothing but jeans so long as the dean insisted on the power to tell me otherwise. The fact that most law school deans would not dream of telling faculty how to dress, even if some probably wish that some faculty dressed more formally, reveals the fundamental significance of power and humiliation in workplace dress codes. They realize they don't

\footnotetext{
${ }^{21}$ Kara Jesella, Beauty Bullies, N.Y. Times StYLE MAGAZINE Spring 2006 at 130 (quoting Michael Solomon of Auburn University).
} 
have the power to control that aspect of law professors' behavior, and they have no desire to risk their own dignity by treading on that aspect of status. Employers of high-status employees rarely attempt to assert the power to request employees project a certain image because they risk losing power rather than gaining it in the confrontation. As noted above, the transgression of the unspoken rule that dress codes remain largely unspoken is one of the appalling features of Hopkins v. Price Waterhouse.

There is a world of difference in choosing to wear something and being forced to wear it. Choosing to wear something is to experience the power to present a self to the world, even if the choice is heavily constrained by social forces and reflects only a decision to blend in by wearing something you would never otherwise choose to wear. (Why would men choose to wear a piece of colored silk knotted tightly around their necks except that it is conventional and in our culture connotes professionalism, elegance, and respect for tradition?) Being told you'll be fired unless you attend a business meeting on Wall Street wearing a pin-striped suit has a whole different connotation than reluctantly choosing to wear one because you know you'll raise eyebrows if you don't. Elite workplaces don't bother with formal dress codes except at the most general level (Is there a casual Friday? Do men wear ties? Do women wear dresses or suits?). That is because power operates quite differently at that status level.

It is important to understand that context is everything in thinking about whether and when dress codes humiliate. When police forces and railroads sought to introduce uniforms in mid-mineteenth century America, their efforts were met with derision and resistance by workers who considered uniforms "degrading in a democratic society" and 
appropriate only for "liveried servants" not "free Americans." 22 Today, of course, most people see nothing degrading about requiring police officers to wear uniforms. Not every dress code is an effort to induce conformity for the sake of conformity, or to assert power. The requirement that employees wear costumes is sometimes about setting a mood (a symphony orchestra) or playing a role (as in Disneyland) and it is sometimes about making employees easily identifiable and distinguishable from others (as in the case of police, soldiers, hospital employees, and flight attendants). And there may be circumstances in which minute attention to the smallest aspects of personal appearance is not demeaning because appearance is so integral to the job (as in the case of actors and fashion models). Appearance requirements, even when they are gendered or racial, in these circumstances connote an entirely different power dynamic than do appearance requirements enforced against athletes or bartenders. The reason has something to do with the tradition of respect for military and police uniforms, and something to do with the widespread recognition that conventions of dress are at the core rather than the periphery of some jobs (playing Snow White for a crowd of children at Disneyland).

There are plenty of cases on the margins, however. Are employees who work in office jobs the fashion industry fair game for unabashed supervisory demands as to their appearance? A recent article in the style supplement to The New York Times Magazine argues not, characterizing as "beauty bullies" supervisors "who demand that their staff look a certain way and aren’t shy about saying so."23 Even if you work in an industry

\footnotetext{
${ }^{22}$ Matthew W. Finkin, Employee Privacy, American Values, and the Law, 72 ChI.-Kent L. ReV. 221, 252 (1996), quoting WALTER LICHT, WORKING FOR THE RAILROAD: THE ORGANIZATION OF WORK IN THE NineteENTH CENTURY 271 (1983), and DAVID MONTGOMERY, CiTIZEN WorkeR: THE EXPERIENCE OF

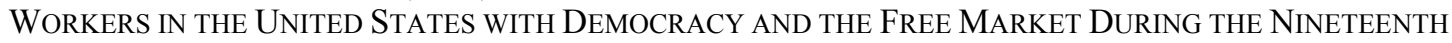
CENTURY 67 (1993).

${ }^{23}$ Kara Jesella, Beauty Bullies, NY TIMEs StYle MAGAZINE, Spring 2006 at 130 ("the stories are legion: the beauty executive who fired a junior staffer who refused to get Japanese hair straightening; the male
} 
that sells beauty, when a publicist says to a subordinate that she needs to dye her hair, pluck her eyebrows, or get a pedicure, the demands can be interpreted not as creating a corporate image but as humiliating a young subordinate. The necessity and the cultural context make some uniforms and appearance requirements a source of fun or pride and others humiliating.

Even when an appearance requirement is generally unobjectionable from the standpoint of individual freedom, however, there may be applications of the uniform requirement that are really about power and humiliation. Antidiscrimination law has traditionally focused on requiring the same treatment of all or different treatment for some, and has had a notoriously difficult time distinguishing when justice is better served by a model of equality or one of difference. ${ }^{24}$ (Think of the long controversy over pregnancy discrimination, religious and disability accommodation, and affirmative action.) When it comes to appearance requirements, one can see that sometimes equal treatment is humiliating and sometimes different treatment is. When the Citadel proposed to force its first female cadet to shave her head like the male cadets, all saw that equal treatment was a way to humiliate a woman whom it believed did not belong in a male institution by forcing her to look like a man to the point of ridicule. ${ }^{25}$ A bank's rule that women had to wear uniforms while men did not was properly seen to be humiliating

editor in chief who explicitly forbade his female employees to wear makeup (which is nothing compared with the famously soignée editrix who insists that prospective hires include Polaroids along with their resumes)").

${ }^{24}$ See, e.g., Christine Jolls, Antidiscrimination and Accommodation, 115 HARV. L. REV. 642 (2001); Samuel Bagenstos, "Rational Discrimination," Accommodation, and the Politics of (Disability) Civil Rights, 89 VA. L. REV. 825 (2003).

${ }^{25}$ See Bartlett, supra note _ at 2571-72 \& n.146 ("Ironically, the ritual of scalp shaving in the militaryschool context is to humiliate and to provide a basis for group bonding. When applied to the only woman in an otherwise all-male environment, however, there should be little doubt that the effect is to set apart the female for whom a bald head means something quite different than for men"). 
to women ${ }^{26}$; conversely, if a police department required men but not women to wear uniforms, most would see that, again, women would be humiliated. The Air Force's refusal to treat an Orthodox Jew differently - prohibiting him from wearing a kepah because head coverings are not worn indoors or at night -- was humiliating because it signified that the Air Force has the power to dictate rules that deny religious expression. ${ }^{27}$ What helps us distinguish humiliation and dignity in equal treatment and different treatment is attention to the ways that controlling dress is an exercise of power.

The focus on screening or signaling which dominate antidiscrimination analysis trains our attention on whether it is acceptable for the employer generally, in the name of signaling professionalism for example, to expect that men dress conventionally, or whether it is acceptable for employers to screen employees by employing only those who adhere to widely-accepted societal norms, as by not exposing tattoos. ${ }^{28}$ Both of these focuses make appearance codes seem trivial. A privacy analysis with its attention to coercion and humiliation, by contrast, reminds us of why appearances matter and helps us identify the situations in which equality should be required and when difference should be required. Privacy doctrine alerts us to the exercise of power and to the question whether an exercise of power is really offensive to freedom and when it is justified by some overwhelming need.

\section{Privacy as Autonomy}

\footnotetext{
${ }^{26}$ Carroll v. Talman Federal Savings \& Loan, 604 F.2d 1028 ( $7^{\text {th }}$ Cir. 1989).

${ }^{27}$ Goldman v. Weinberger, 475 U.S. 503 (1986) (holding that Jewish officer did not have first amendment right to wear yarmulke in contravention of Air Force regulation prohibiting the wearing of headgear indoors).

${ }^{28}$ See Brandy Dela Vega, Tattoos in Business: OK or Taboo? Reno GAZETTE-Journal, Mar. 5, 2006.
} 
At its origins, the invasion of privacy tort was like the tort of outrage (now known as intentional infliction of emotional distress) in its emphasis on humiliation. ${ }^{29}$ Like intentional infliction of emotional distress, privacy focuses on how some behaviors assault a person's autonomy by affronting their dignity or psyche, just as other torts such as assault or battery, injure by invading autonomy through threats or actual physical touching. Privacy was seen as a tort doctrine that would protect the individual against the harms of abuses of power in society.

In the years since invasion of privacy was first regarded as being a legal wrong, the protections for privacy have spread through tort law, constitutional law, and statutes. Different states define a right to workplace privacy in different ways, and protect it under a variety of doctrines, including statutes, the various permutations of the privacy tort recognized by the Restatement of Torts, a public policy claim, a constitutional claim (for public sector employees and, even in private employment in California, where the constitutional right of privacy does not have a state action requirement ${ }^{30}$ ), the covenant of good faith and fair dealing (in Alaska), ${ }^{31}$ and in cases of extremely offensive policies like strip searches, the intentional infliction of emotional distress. ${ }^{32}$ Most jurisdictions recognize that a right of privacy, however protected, extends both to what employees do

\footnotetext{
${ }^{29}$ See WiLliam L. Prosser, LAW OF TORTS 802 ( $4^{\text {th }}$ ed. 1971) (early advocates for a right of privacy emphasized need to protect "private individuals against the unjustifiable infliction of mental pain and distress"); Samuel D. Warren \& Louis D. Brandeis, The Right to Privacy, 4 HARV. L. REV. 193 (1890) (arguing that common law protects "thoughts, emotions, and sensations" as well as physical integrity and property, and therefore that a right of privacy is a logical outgrowth of legal protections against defamation, assault, and theft of intellectual property)

${ }^{30}$ See Soroka v. Dayton Hudson Corp., 1 Cal. Rptr. 2 d 77 (Cal. App. 1991); CAL. Const. Art. I, sec. 1. The California constitutional right of privacy was added by ballot initiative in 1972, and the ballot arguments favoring it explicitly mentioned employment as an area needing legal regulation to protect employee privacy. See Soroka, 1 Cal. Rptr. 2d at

${ }^{31}$ Luedtke v. Nabors Alaska Drilling, Inc., 834 P.2d 1220 (Alaska 1992).

${ }^{32}$ The legal protections for a right of privacy in employment are comprehensively discussed in MATTHEW W. FINKIN, PRIVACY IN EMPLOYMENT LAW (2d ed. 2003).
} 
at work (for example, through audio or video recording of the workspace) and what they do away from work (for example, social and political activities or affiliations).

Whatever the source of the privacy right, under most states' laws, the analysis boils down to the same four questions. First, how serious or offensive is the invasion of employee privacy? Second, does the employee have a subjectively genuine and objectively reasonable expectation of privacy, or expectation of freedom from employer control? Third, does the employer have a legitimate reason for its policy and, if so, how compelling is its reason? Fourth, could the employer serve its legitimate interest through some other policy that is less invasive?

I recognize that in most states privacy rights in the workplace, if they exist at all, are quite narrow and weak. The doctrinal discussion that follows is not intended as an argument for why existing doctrine already solidly supports a right of employee autonomy in matters of appearance. Existing doctrine probably does not support such a right in the majority of states. Rather, the discussion that follows is intended as a jurisprudential exercise to explore how, if a robust right of privacy did exist in a state, such a right could be extended to cover the autonomy right of employees to choose their appearance absent some legitimate employer justification. In such a world, analysis of dress codes through a privacy rubric would look something like this.

First one would consider how significantly the dress code restricts an employee's freedom of choice in dress. This is the equivalent of asking how seriously or offensively a workplace rule intrudes upon an employee's privacy. A general requirement of neat grooming is generally not a serious intrusion. The Jespersen regime of a large amount of make-up, nail polish of specified colors, and "curled, teased or styled hair" is a 
substantial intrusion. ${ }^{33}$ The system that requires the supervisor to compare an employee's daily appearance to a photograph taken after a make-up artist and hair stylist "made over" the employee and, presumably, to berate the employee if her looks on a particular day diverge too far from the photo is quite intrusive. A requirement of wearing a uniform, particularly the requirements regarding the minute details of the dress uniform imposed by the armed forces, is a substantial intrusion. A general requirement of wearing a conservative suit and tie is a less significant intrusion in most cases, although a particular employee from some non-Western culture might find it very intrusive.

The second step asks about the employee's expectation of freedom from intrusion. This has both a subjective and an objective element. The subjective element should examine the characteristics of the employee to determine whether the appearance code violates some aspect of the employee autonomy that the employee regards as crucial. A Sikh man or a Muslim or Orthodox Jewish woman would regard uncovering their hair as a major intrusion, someone who just likes to wear a hat might or might not. On the other hand, the claim does not have to be religious in order to survive: thus, there would be no distinction (unlike under current law) between a woman who wore a headscarf for religious reasons and one who wears one for cultural reasons. ${ }^{34}$ Does the employee refuse to wear make-up because of a consistent or profound objection to it, or does she

\footnotetext{
${ }^{33}$ The "Personal Best" grooming policy was exceptionally detailed. It specified that "[h]air must be teased, curled, or styled every day you work. Hair must be worn down at all times, no exceptions." Further, it dictated particular quantity, types and colors for make-up: "Make-up (foundation/concealer and/or face powder, as well as blush and mascara) must be worn and applied neatly in complimentary colors." "Lip color must be worn at all times." 392 F.3d at 1077-78 \& nn.1-2.

${ }^{34}$ See Isaacs v. Board of Education, 40 F. Supp.2d 335 (D.Md. 1999) (rejecting the claim of a school girl who sought to wear a headwrap of the Caribbean style because her headwrap was neither political speech nor religious exercise); United States v. Board of Education, 911 F.2d 882 (3d Cir. 1990) (teacher has no right to wear headscarf); Justice Backs Muslim Girl in Headscarf Case, FinanCial Times, Mar. 31, 2004 (U.S. Department of Justice intervened in a suit brought by a Muslim sixth-grader and her family challenging ban on headscarves).
} 
just feel too lazy to put it on one day? Skeptics worry that emphasis on subjective claims of harm would empower an employee to claim that wearing a baseball hat, say, is as important to him as wearing a headscarf is to a Muslim woman. I think that fear is overblown. To raise a triable issue of fact (or to convince a jury) on the existence of a sincere but subjective claim of injury, the employee would have to offer evidence that he always wears a hat and that the baseball hat occupies a place in his life that religious head coverings do in the lives of the devout. There may be some frivolous cases, just as people occasionally succeed in making frivolous claims as to whether their religion requires particular dress or practice. But I am not so doubtful of the ability of judges and jurors to sort these cases out that I am willing to sacrifice the autonomy rights of the nonreligious to dress in the way that is important to them.

A different fear about using the right of privacy to challenge workplace appearance codes focuses on the ease with which employers can eliminate expectations of privacy simply by announcing their intention to intrude upon privacy regularly. Could Harrah's, for example, defeat Darlene Jespersen's privacy claim by asserting that in the casino industry looks matter and that employees who work in the field should expect minute attention to their looks, just as they should expect to be videotaped every moment they are on the gambling floor in order to protect the safety and honesty of the operation? Here, again, thoughtful analysts of the right of privacy recognize that the law needs to be reasonable. If an employer can defeat any right of privacy simply by announcing its intention to allow no privacy, the right is eviscerated, just as the constitutional right of privacy could in theory be eviscerated by the government's announcement that henceforward we'll all have government-monitored cameras in every room of our homes. 
The expectation of privacy, most agree, is more than a function of whatever the powersthat-be will vouchsafe to us at any given moment.

An additional check on frivolous claims is offered by the requirement that an expectation of privacy be objectively as well as subjectively reasonable. The objective element would examine the characteristics of the workplace to try to grasp the connotations of an appearance requirement to assess whether the reasonable person would find particular appearance regulation an offensive invasion of autonomy. Regulation of hair length in the military has different connotations than it does if you work at the Gap. A buzz cut means something different for men than it does for women, and would objectively be regarded as humiliating for a woman but not a man.

Established law asks, third, about whether the employer has a good reason for its requirement. Here privacy analysis has a real advantage over discrimination analysis because it will enable a more thoughtful (or maybe just more middle-of-the-road) approach to whether tradition or employer or customer preferences justify a dress code. If the offense of the dress code is generally small, then tradition is probably sufficient. Thus, if it's conventional to wear a suit and tie on Wall Street, there is nothing wrong with requiring men to wear suits and ties unless the man has some strenuous and good objection (such as his religion). The armed forces might be able to enforce all of their uniform requirements, including the picayune ones about which ribbon is worn on which part of which coat at which time of day, but not, against an Orthodox Jew, the requirement that men have their heads uncovered indoors or at night.

The strength of the employer's justification for its appearance requirements mirrors the function of the BFOQ (in the case of expressly discriminatory dress 
requirements) or the business necessity defense (in the case of dress requirements that are neutral on their face but have a disparate impact). Take the example of safety. A requirement that firefighters or airline crew refrain from wearing beards might be justifiable if it can be proven that in fact a beard prevents the proper fit of an oxygen mask. $^{35}$

Fourth, and finally, privacy analysis asks about whether the employer's asserted reasons for the appearance requirement could be achieved in some less intrusive manner. If a uniform is necessary in order to distinguish employees from members of the public, as in the case of airline flight attendants, is it really necessary that the uniform be sexy? Would it have to require women to wear skirts? If the symbolism of minute attention to every detail of military uniforms is necessary to enable people to read each other's rank at a glance, it may be permissible to regulate to the nth degree where people wear ribbons on their uniform. But that same attention to detail may not necessitate that men refrain from wearing head covering. If that requirement is supported only by tradition, perhaps that requirement can give way to a particular employee's strong religious beliefs without jeopardizing the uniform requirement in all its other minute details.

An important question to consider is the allocation of the burden of proving the various elements. I propose a divided burden of proof, basing the division on who is more likely to have access to the necessary evidence. Some elements should surely be on the employee - the intrusiveness of the regulation, the sincerity and reasonableness of the employee's belief that particular dress habits are expressive of her identity and that the employer's contrary rule compromises her autonomy in a significant way. Some elements should probably be upon the employer, such as the justification for the

${ }^{35}$ See, e.g., Potter v. District of Columbia, 382 F. Supp. 2 d 35 (D.D.C. 2005). 
appearance requirement and the inability to achieve its goals through a less intrusive policy or the inability to make an exception for a particular employee. For example, even if one were prepared to uphold the right of the Air Force to prohibit headgear indoors under most circumstances, exactly what was so compelling about the Air Force's requirement that men refrain from wearing head covering that it could not make an exception for a rabbi? Would it really cause every Air Force officer to insist on wearing their uniform hats, or baseball hats?

The foregoing is just a sketch of how privacy law might approach workplace appearance requirements. It suggests that privacy analysis not only enables sincere and compelling claims of autonomy to be respected, not just those that can be identified as linked to a particular protected class, but also allows employers to enforce dress codes in many cases upon a showing of necessity. Unlike current law, it would allow racial appearance requirements if the employer can prove they're really necessary (whereas currently there is no BFOQ for race), while doing a better job than existing law of forcing employers to justify arbitrary and oppressive appearance requirements even when they do not discriminate. Let me now turn to a more systematic comparison of a privacy analysis and the dominant antidiscrimination framework, and also consider some likely objections to my proposal.

\section{Humiliation Versus Discrimination}

\section{A. Discrimination Analysis of Dress Codes and Its Problems}

For the forty years that Title VII has been in force, legal analysis of workplace dress codes has focused almost exclusively on whether they discriminate on the basis of 
status; gender, race, or religion. Commentators and history have not been kind to the efforts of courts to decide which social norms of dress are legal and which are not. ${ }^{36}$ All of the various approaches that courts have used are either too deferential to employer preference, on the one hand, or unable to persuade those who think that some employermandated gender difference in attire ought to be legally permissible. Under antidiscrimination law, a court that believes workplace dress code is acceptable must either conclude that it does not discriminate or that the discrimination is justified as a bona fide occupational qualification (BFOQ) based on the preferences of the employer or the customers. Neither conclusion seems very appealing to many courts.

First, the per se approach, which held that any employer-mandated gender difference in appearance was sex discrimination, risks undermining the limits on the BFOQ defense by allowing stereotypes or employer or customer preference to be enough to justify discrimination. ${ }^{37}$ Most commentators, and many courts outside the appearance regulation area, insist that the BFOQ defense should be very narrowly circumscribed in order that firms not be allowed to rely on hidden bias, stereotype, or discriminatory customer attitudes to justify discriminatory practices. Thus, in Johnson Controls, the leading case on the sex-based BFOQ, the Supreme Court rejected the contention that the risk of birth defects caused by lead exposure sufficed to justify a rule that prohibited fertile women from working in battery production. The Court insisted that the BFOQ defense be construed "narrowly" and be limited to circumstances in which there was

\footnotetext{
${ }^{36}$ See sources cited supra note

${ }^{37}$ I owe this typology of different approaches to dress codes to Erica Williamson, whose Note sorted out the cases and the dominant critiques of them. [cite]
} 
evidence that employees of one sex could not do the job as efficiently as employees of the other sex..$^{38}$

Commentators have remarked on the inescapable role of community norms in deciding when adherence to certain gendered appearance requirements is the "essence" of a business. ${ }^{39}$ In an early case involving an older business model of Southwest Airlines, in which Southwest advertised itself as the "Love Airline," marketed the sex appeal of its flight attendants to its target clientele of male business travelers, the court rejected the contention that the essence of Southwest's business was selling sex appeal plus safe air travel, and insisted instead that safe air travel was the business. ${ }^{40}$ Who is to say whether the essence of Hooters' business is selling food or selling sex appeal plus food? Could a law firm legally say that the essence of the business is to satisfy client preferences, including, as a lawyer in my early career once described a client's preference for an associate who was a "goyisha girl with big charlies"? If a court believes a discriminatory dress code can be upheld as a BFOQ, it is a bit difficult to understand why the preference of an employer or its customers for women in make-up or men in neckties should be honored whereas the preference of an employer or its customers for only young and handsome employees, or only unmarried employees, ${ }^{41}$ or only non-Muslim employees, or

\footnotetext{
${ }^{38}$ International Union United Auto Workers v. Johnson Controls, Inc., 499 U.S. 187, 206 (1991) (BFOQ requires that the "employer must direct its concerns about a woman's ability to perform her job safely and efficiently to those aspects of the woman's job-related activities that fall within the "essence" of the particular business").

${ }^{39}$ See, e.g., Bartlett, supra note

${ }^{40}$ In both Wilson v. Southwest Airlines Co., 517 F. Supp. 292 (N.D. Tex. 1981) (which involved the "Love Airline" marketing campaign), and Diaz v. Pan American World Airways, Inc., 442 F.2d 385 ( $5^{\text {th }}$ Cir. 1971) (in which Pan Am justified its refusal to hire male flight attendants with expert psychiatric testimony that the special psychological needs of passengers in an airplane are better attended to by females), the courts rejected the contention that the essence of the airline business is selling comfort or sex appeal rather than merely safe air travel.

${ }^{41}$ See, e.g., United Airlines, Inc. v. McDonald, 432 U.S. 385 (1977) (describing the range of litigation challenging sex discrimination by airlines in hiring flight attendants); Sprogis v. United Air Lines, Inc., 444 F.2d 1194 ( $7^{\text {th }}$ Cir. 1971) (declaring the airlines' no-marriage rule for female flight attendants unlawful).
} 
only men and infertile women in battery production facility, ${ }^{42}$ should not be honored.

The alternative to allowing biased employer or customer preferences to govern is to prohibit any appearance regulation that was not entirely androgynous.

An alternative to the per se rule, with its inevitable struggles over the scope of the BFOQ, is the mutability analysis, which held that appearance codes are permissible because they do not discriminate based on immutable characteristics (race, sex, or national origin). The mutability analysis is vulnerable to the argument that Title VII prohibits discrimination on mutable traits (religion) and trait-plus discrimination even when the "plus" is entirely mutable (employer discrimination against women who are married $^{43}$ or who have small children ${ }^{44}$ is illegal, though both of those traits are mutable). The variation on the mutability rule, that Title VII prohibits discrimination only based on immutable traits plus fundamental rights (which would protect religion and family status) still is vulnerable: an employer that hired men only if they can play tennis without applying the same requirement to women, or that refused to hire women but not men who bowl, would violate Title VII even though playing tennis and bowling are not generally regarded as fundamental rights. ${ }^{45}$

A third approach to discriminatory dress codes is the one employed most recently in Jespersen: the unequal burdens analysis, which allows appearance codes that equally

\footnotetext{
42 Johnson Controls, 499 U.S. 187.

${ }^{43}$ Sprogis, 444 F.2d at 1198.

${ }^{44}$ Phillips v. Martin Marietta Corp., 400 U.S. 542 (1971)(per curiam).

${ }^{45}$ See id. at 543 (holding that discrimination on the basis of sex plus another trait is illegal). While some commentators have noted that some of the cases challenging appearance codes have remarked that sex-plus discrimination is unlawful only if the trait is immutable or a fundamental right, see Yuracko, Trait Discrimination, supra note _ at 205 \& nn.145-47 (collecting citations), there are other cases, including Price Waterhouse, in which courts have found trait discrimination to be illegal even when the sex-plus trait is not immutable. I have a hard time believing that a court would uphold an employment rule prohibiting women but not men from bowling if any employer were silly enough to enforce one.
} 
burden men and women or other comparison groups. ${ }^{46}$ Its principal flaw is that it invites silly and utterly subjective comparisons: Is wearing a necktie more or less burdensome than wearing panty hose? Does it matter whether it is winter or summer? Is shaving one's face more or less burdensome than applying make-up and nail polish? What should a court do about the claim of a particular man who especially loathes a discriminatory appearance requirement (like shaving or putting on make-up) if most say they don't particularly mind it?

The conceptual failings of the dominant forms of discrimination analysis as applied to dress codes go deeper than the overbreadth or underinclusiveness of the existing rules. The notion that gendered or ethnic dress codes are illegal only because they discriminate is, in some cases, artificial. It fails to capture many of the reasons why employees object to particular appearance regulation. Men in the 1960s did not grow their hair long in order to look like women, and the offense of making them cut their hair was not that they were not allowed to wear their hair like women but that they were not allowed to express the non-gendered message that long hair connoted. Men who wear long hair aren't necessarily (or even usually) gender-bending: long hair symbolizes other things - in the 1960s it signified rebellion against power, convention, and the older generation; it can signify authentic Native American identity; it can signify earthiness. ${ }^{47}$

\footnotetext{
${ }^{46}$ Jespersen v. Harrah's Operating Co., Inc., 392 F.3d 1076 (2004), reh'g en banc granted, 409 F.3d 1061 (2005).

${ }^{47}$ I am reminded of the Crosby, Stills Nash (\& Young) song, "Almost Cut My Hair,” which celebrates long hair as a badge of independence:

Almost cut my hair

It happened just the other day

It's gettin' kind of long

I could've said it was in my way
} 
The make-up requirement to which Darlene Jespersen objected is more obviously a case of gender discrimination in that wearing make-up is clearly about feminine sexuality. But even women who are happy to wear make-up when they choose might be offended by being forced to wear a certain quantity and to have their compliance checked.

The essentialism of discrimination analysis is its reliance on the idea certain appearance conventions are "white" or "black" or "male" or whatever. Some whites and some blacks can wear their hair in an Afro, some of both races cannot. When a court rejected the claim of a black flight attendant who was fired for wearing her hair in cornrows by pointing out that the hair style wasn't "black" because Bo Derek popularized braids in the movie "10," the court refused to acknowledge that for that flight attendant, wearing her hair in cornrows was an important expression of her racial identity, whereas the same hairstyle on a white woman may connote something entirely different. ${ }^{48}$

\section{B. The Advantages of Privacy Analysis}

There are several advantages, both practical and doctrinal, for re-examining workplace dress codes in terms of autonomy-privacy. The advantages fall into two categories. First, privacy analysis does a better job than discrimination analysis of balancing competing employer and employee interests by calibrating the strength of the employer interest in regulating appearance to the degree of autonomy infringement that regulation causes. Second, privacy is a right that all enjoy, thus the legal protection is extended to every person because of their individuality, not only to members of those

But I didn't and I wonder why

I feel like letting my freak flag fly

$\cdots$

${ }^{48}$ Rogers v. American Airlines, Inc., 527 F. Supp. 229, 232 (S.D.N.Y. 1981); Paulette M. Caldwell, A Hair Piece: Pespectives on the Intersection of Race and Gender, 1991 DuKE L. J. 365. 
groups who are protected by antidiscrimination law and who can convince a court that a dress code treats some groups better than others.

\section{Calibration and Nuance}

A legal strategy that focused on discrimination was always vulnerable to the fears of the extreme argument. To take the argument to its logical conclusion, skeptics routinely claimed, would prohibit employers from requiring employees to adhere to conventions for professional dress (men must wear suits and ties; women can and sometimes must wear suits but not neckties). It would, skeptics insisted, either compel an employer to employ a drag queen in a customer service position or to require all employees to dress entirely androgynously so that women would be prohibited from wearing long hair, make-up, dresses, or high heels if they choose. Both contentions are often taken as argument-stoppers. Once you concede, as Katharine Bartlett did and I do, that Title VII should allow some dress codes that reflect community norms while rejecting others, you have a tough time deciding which norms the law can and should change or reject and which it should accept. ${ }^{49}$ Privacy analysis helps, for it reminds courts and employers that all of us have to conform to some norms of appearance some of the time, but that no one should be required to conform to every norm all the time regardless of the harm inflicted or the strength of the justification.

The doctrinal structure of privacy law invites flexibility and nuance in the examination of the degree to which the policy is offensive (both across the board and as applied to particular employees), the strength of the justification for a policy that does invade privacy, and the question whether there are other ways that the employer could

\footnotetext{
${ }^{49}$ Katharine T. Bartlett, Only Girls Wear Barrettes: Dress and Appearance Standards, Community Norms, and Workplace Equality, 92 MicH. L. Rev. 2541 (1994).
} 
achieve its legitimate goals with a lesser infringement on the employee's autonomy.

Antidiscrimination law, by contrast, makes almost no effort to examine the offensiveness of a policy and tends to do a poor job at allowing nuance in the question of justification and fit because of the concern that accepting too many things as a BFOQ will eviscerate the prohibitions against discrimination.

Moreover, privacy law explicitly incorporates an analysis of justification and narrow tailoring that antidiscrimination law does only in part. When it comes to race, because there is no BFOQ for race in Title VII, in theory there is no justification, no matter how compelling, for an employer to discriminate. ${ }^{50}$ As to other protected traits, courts have tried (outside the context of appearance codes and Hooters) to limit the circumstances in which employer or customer preference counts as a BFOQ to a set of narrow special categories. When the justification is asserted for a form of disparate impact discrimination, as in the case of the duty to accommodate religion, the law is far more forgiving of an employer's choices that disparately burden people of one religion over another. Neither in the case of BFOQ nor business necessity have courts been as thoughtful as one might like about tying the degree of harm to the strength of justification to the fit between the justification and the policy that inflicts the harm. Privacy analysis, at its best, insists that courts and lawyers think critically at all three steps.

\section{Privacy for All}

One is that privacy doctrine is the one place in employment law where courts have recognized that there are boundaries to the employer's ability to regulate the

\footnotetext{
${ }^{50} 42$ U.S.C. 2000e-2(e). Many think there is an unwritten BFOQ for race (police departments use race in assigning undercover cops, movie makers use race in casting, and law firms use race in assigning lawyers to handle a race-sensitive trial). See Paul Frymer \& John D. Skretny, The Rise of Instrumental Affirmative Action: Law and the New Significance of Race in America, 36 ConN. L. REv. 677, 680 (2004).
} 
workplace in ways that impinge on the employee's sense or expression of self. Rather than focusing on equal as opposed to special treatment (is it equality or discrimination to require all cadets at the Citadel to shave their heads or all Air Force officers to wear no head covering at certain times?) privacy focuses on the right of employees to have a sphere, whether it is the contents of their desk, the content of their thoughts, the contents of their weekend calendar, or the style of their hair that is free from employer control absent a strong justification.

Second, privacy helps address the conventional complaint that only "favored" groups are protected by the law. As Kenji Yoshino has pointed out, everyone has to do some things regarding their appearance that they don't like - what he calls "covering" in order to put on the façade that is expected in different work settings. ${ }^{51}$ While it is true that WASP men are protected under Title VII too, and thus on the right facts a white man could sue to challenge appearance regulation, there is a widespread perception among whites that people of color, religious minorities, and women have greater workplace protections because they get to choose whether to acquiesce in a gender- or racestereotyped dress code or whether to fight it. A privacy theory is available to any employee who can convince a court that some aspect of a dress code is offensive to their authentic self.

Third, privacy law moves the focus away from antidiscrimination law's emphasis on group membership, immutable traits, and group exercise of fundamental rights and toward the ways in which appearance regulation can harm people because of their individuality rather than their group membership. By putting the focus on autonomy and the limits on self-expression at work, the law would extend to all employees a right to

\footnotetext{
${ }^{51}$ KenJi YoshinO, COVERING (2006).
} 
legal protection for authentic expression as each person feels it. Moreover, privacy analysis would turn the old antidiscrimination analysis (forced lawyers to argue for the immutability of identity) on its head. It is the mutability of appearance and the choices that each person makes about how to express themselves through their appearance that make workplace dress worthy of legal protection.

Not only does a privacy analysis avoid the fearsome specter of the man "minc[ing] around in high heels," $" 52$ it also captures an element of dress regulation that is missing from the conventional analysis. Considering appearance regulations from the standpoint of antidiscrimination law misses a fundamental part of why employers impose them, why employees find them objectionable, and why the law should restrict it. Moreover, prohibiting only those applications of dress codes that discriminate on the basis of a protected status leaves vulnerable those employees who either do not find or cannot prove that their objection to a dress code is based on a protected identity characteristic. Conceiving them as invasions of the autonomy that the right of privacy protects, however, catches more of the nuance about when and why they should be prohibited.

\section{Anticipating Objections}

Let me now address a number of the objections one might make to my proposal. First, there is the obvious but facile criticism that a right of privacy seems a poor choice for protecting something that is as quintessentially public as the public face we set for the world. A right of privacy is a misnomer, at least in some of its applications in both an

\footnotetext{
52 Hamm v. Weyauwega Milk Products, Inc., 332 F.3d 1058, 1067 (7 $7^{\text {th }}$ Cir. 2003) (Posner, J., concurring) (complaining that case law on sex stereotyping "has gone off the tracks" in reasoning "as if there were a federally protected right for male workers to wear nail polish and dresses and speak in falsetto and mince about in high heels, or for female ditchdiggers to strip to the waist in hot weather")
} 
employment relationship and more obviously in constitutional discourse. It protects all sorts of behavior that is not necessarily hidden from view; it protects a boundary between the self and the world, or between one's personal life and one's work life. As many have observed, privacy should be about autonomy, rather than secrecy. Some versions of the common law right of privacy protect public information (like a photograph of your face) when the harm to your dignity or autonomy comes not from revelation of private information but from falsely associating your identity with a product or portraying you in a false light. $^{53}$

A more serious objection is that the employee's autonomy right collides with the employer's autonomy right to put its face before the world through the faces of its employees. This is a point elegantly raised by Robert Post in his work on appearance and discrimination, Prejudicial Appearances, when he commented on an ordinance that was proposed (but not ultimately enacted in its most vigorous form) that would have prevented employers from discriminating based on employee appearance. ${ }^{54}$ An advocate of the ordinance described the discrimination she experienced because employers felt threatened by a woman with a shaved head, save for a single patch of bright pink hair, and a stripe tattooed on her face. Post observed some inconsistency between the woman's awareness and embrace of the shock conveyed by her appearance and her belief that she should be free from adverse employment action because of the reactions her looks elicit. He remarked on "the seemingly paradoxical notion that persons have the right both to use their appearance to communicate meanings, including messages of

\footnotetext{
${ }^{53}$ PROSSER, supra note _ at 804-807 (discussing the appropriation, for defendant's benefit, of the plaintiff's name or likeness), 812-814 (discussing false light privacy).

${ }_{54}$ Post, Prejudicial Appearances, supra note _; ROBERT C. Post, K. ANTHONY APPIAH, Judith Butler, Thomas C. Grey \& Reva B. Siegel, PreJudicial Appearances: The Logic of American ANTIDISCRIMINATION LAW (2001).
} 
'threat,' and simultaneously expect others to ignore these messages." ${ }^{, 55}$ A resolution of the paradox, if there is a paradox, can be reached if we use law to force people to confront exactly what meaning is conveyed by a sales clerk with a shaved head, a lawyer with blue hair, or a cross-dressing insurance agent.

There are two parts to the analysis. First, there is the idea that firms have a right to express themselves through their employee's appearance. The heart of the opposition to appearance regulation is the idea that it deprives the employer of its autonomy right to to express itself through the faces of the people it hires. I question whether employers, even when they are individuals, and even when the job in question has an important component of conveying certain values, have a right to express themselves through their employees regardless of the message. Take the extreme case of employer autonomy: where I am hiring a nanny to care for my children. Why should I be able to require her to wear a uniform, if the message conveyed by domestic staff wearing a uniform is one of subordination (as I think it is)? Why should the owner of a spa be able to require "badly coiffed employees" to get their hair cut? ${ }^{56}$ What message $i s$ conveyed by an employee of a spa having a hair cut that the spa owner doesn't like?

Whatever the force of the employer autonomy argument when the employer is an individual or a small business, when the business can be seen to express the individuality of the person who owns it, I question whether a corporation has a similar right. Courts have been reluctant to extend to corporations the same panoply of associational and expressive rights that individuals enjoy, recognizing that the expression of corporate expression or association rights comes at the expense of employees' rights to be free from

\footnotetext{
${ }^{55}$ Post, supra note _ at 7.

${ }^{56}$ Beauty Bullies, supra note _ at 130.
} 
discrimination. ${ }^{57}$ Whose expression are we protecting? The managers, executives, or stockholders of corporations? In what sense do the shareholders of Harrah's casinos express themselves through the bartender in Reno? The argument usually gains traction only when it is taken to an extreme in one direction or another. A fashion industry executive who suggested an employee get a pedicure before wearing a pair of sandals to an industry gala would defend her position by saying that in her industry people are judged on their looks, and that even a single employee whose feet might prompt someone else in the industry to think the employee was unattractive could somehow adversely affect the reputation of the firm. ${ }^{58}$

Even if you assert that corporations should have a right of expression in this context, as they have a right to engage in first amendment speech, ${ }^{59}$ one might still question whether a corporation's right to express itself through employee appearance that is sufficiently compelling to trump an employee's right to express herself. In the first amendment context, the expressive interests of associations is generally limited to those associations (whose ranks may have grown after the Supreme Court upheld the right of the Boy Scouts to express a homophobic message by the exclusion of gays) that can credibly claim to be sufficiently private and sufficiently devoted to expression that it would violate the rights of the members to join together with those who share their views and to exclude those who do not. It is a huge leap to move from a private organization's expressive interests in excluding gays to the right of large corporations to express

\footnotetext{
${ }^{57}$ See, e.g., Roberts v. United States Jaycees, 468 U.S. 609 (1984) (Jaycees organization has no right to exclude women from membership); Boy Scouts of America v. Dale, 530 U.S. 640 (2000) (Boy Scouts have expressive right to exclude gays).

${ }_{58}^{58}$ Beauty Bullies, supra note _at 130.

${ }^{59}$ See First Nat'l Bank v. Bellotti, 435 U.S. 765 (1978) (statute that prohibits corporations from expending funds to influence the vote on ballot measures violates the first amendment).
} 
themselves in their hiring decisions; if you make that move, of course, all of contemporary antidiscrimination law is constitutionally suspect. ${ }^{60}$

Second, even if you accept the notion that firms have some legally protectable right to express themselves through their employees' appearance, you have to ask what message is conveyed by a firm that employs a person with unconventional or shocking (to some) appearance? Consider tattoos and headscarves as examples.

Tattoos. The meaning of tattoos appears to be undergoing a significant transition in the contemporary U.S. Once considered the favored adornment of sailors of the lowest rank, and later regarded the insignia of renegade motorcyclists and gang members, tattoos are now said to be widely accepted among the younger generation. A 2003 Harris online interactive poll, as reported in a Nevada newspaper, found that thirty-six percent of people between the ages of 25 and 29 have at least one tattoo, as compared to a quarter of those in their $30 \mathrm{~s}^{61}$ The news article portrayed the perception of tattoos as being very generationally specific: younger people think nothing of them; older people find them slovenly, repulsive, or even intimidating. If the justification for allowing employers to prohibit tattoos is customer reaction (though it is not always that; some even argue that employers can inquire about and refuse to hire based on tattoos that are not visible when the employee is clothed ${ }^{62}$ ), what weight should we give to the possibility that the employer is misjudging customer reaction? The growing popularity of tattoos suggests that their meaning is changing. The employer's message in banning them may be muddier than it once was, which should reduce the weight of whatever interest the

\footnotetext{
${ }^{60}$ Erwin Chemerinsky \& Catherine Fisk, The Expressive Interests of Associations, 9 WILLIAM \& MARY BILL OF RIGHTS J. 595 (2001).

${ }^{61}$ Tattoos in Business, supra note _.

${ }^{62} \mathrm{Id}$.
} 
employer has in regulating that aspect of employee self-expression. If tattoos are no longer a reliable predictor of a bad attitude toward authority or toward work, it is hard to imagine any legitimate employer interest in refusing to hire employees with tattoos that are not visible while the employee is clothed.

Headscarves. The furor over French legislation banning headscarves in schools raised the question whether the ban was about preserving a secular society, protecting girls against repressive religious demands, or repressing Muslim identity. A careful student of the debate over the legislation could find a mix of these motives in the ban. ${ }^{63}$ The wearing of the headscarf itself could reflect the wearer's attempt to convey one or more of multiple messages, including religious piety, gender subordination, or ethnic pride. You could see in the Muslim women who insist on headscarves a desire to embrace an ethnic heritage or pride that becomes all the more fierce as they perceive a rising tide of anti-immigrant sentiment among non-Muslim French. You could see a desire to find the comfort of ethnic identity as an antidote to the alienation and anomie of persistent poverty in the grim housing projects outside Paris. And of course the interpretation of the headscarf by viewers could vary as well. What some French may once have deemed a relatively innocuous or charming ethnic or religious tradition might now be regarded as an endorsement of separatism, chauvinism, or even anti-European violence. In short, you cannot understand the multiple messages both implied by women who wear headscarves and inferred by people who view them without understanding the social and political context of the Muslim and African immigrant population in France.

\footnotetext{
${ }^{63}$ John Valery White, Globalism and the American Civil Rights Model: Toward an Assimilation Law (publication forthcoming in the proceedings of the XVII Colloquio Biennale, AIDC) (manuscript on file with the author).
} 
But the fact that you need to understand the context of group identity in order to grasp the multiple meanings of certain habits of dress does not mean that they would become unintelligible if we supplemented the dominant antidiscrimination analysis with a privacy analysis. My point, rather, is that we'll need some understanding of the groupbased identity formation that people engage in when they make choices about their appearance in order to understand why some appearance regulations are permissible and others are not. The messages conveyed by habits of dress and personal adornment are varied, extremely context specific, and change rapidly. The wearer, the employer, and the customer may be conveying and receiving quite different messages. Awareness of the group-based identity formation that dress performs, an awareness of the equality issues implicated in appearance regulation strengthens rather than weakens the claim for privacy protection. In particular, given the muddiness in the signal, but the undeniable hardship on an employee who is fired or not hired because of her appearance, it seems to me that the employer's argument for self-expression through employees' bodies is weaker than the employees' arguments.

Another objection to my proposal goes to the question whether, if we divorce the legal analysis of appearance regulation from antidiscrimination analysis, we will lose our understanding of why appearance regulation matters. Every observer of appearance regulation, at least since Erving Goffman's influential (and newly resurgent) book Stigma, has noted that appearances are meaningful because they enable both the viewer and the viewed establish a social identity by association with a category. Today's favorite citation for that same observation is Malcolm Gladwell's bestselling work, Blink, 
which documents the importance of snap judgments formed on first impressions. ${ }^{64}$ That is, appearances identify us as members of a group, and they are meaningful only in the context of particular cultures. A headscarf can be religious (on a nun or a Muslim woman), ethnic (on a person expressing Caribbean identity or heritage), or glamorous (on a Hollywood movie star riding in a convertible in the 1950s). Lots of gold jewelry can be "ghetto fabulous" on a black person, ${ }^{65}$ or a traditional display of wealth and status in India, or glamorous on the wife of a Texas oil magnate shopping in Beverly Hills, or trashy among certain New England old money sorts who disdain conspicuous displays of wealth. The importance of appearance as an expression of self is meaningful only in the context in which appearance says something about you (or at least you think it does), and that has necessarily something to do with group identity.

I think that reconceiving workplace appearance regulation in terms of privacy will not sacrifice the group identity based understanding of why appearances matter and why protecting employees' rights to choose appearance is important in the ongoing project of eliminating racial, gender, and other forms of subordination. It will strengthen the project by forcing us to recognize that appearance rules that do not discriminate on the basis of a protected class (like tattoos or green hair) nevertheless subordinate an out group and do so in a way that is often unjustified by business necessity and based largely on ill-

\footnotetext{
${ }^{64}$ Malcolm Gladwell, Blink: The Power of Thinking Without Thinking (200_); see Beauty Bullies, supra note _ at 130 (companies have appearance guidelines because of the power of first impressions, citing $\overline{B l}$ ink for the proposition that we make our most important decisions based on first impressions).

65 Michael Specter, I Am Fashion: Guess Who Puff Daddy Wants to Be? THE NeW Yorker Sept. 9, 2002 (To attend a fashion show in Paris, Puff Daddy "would have to look, in the phrase coined by Andre Harrell, his former boss at Uptown Records, 'ghetto fabulous.' That meant choosing appropriate accessories: a silver tie, smoke-colored sunglasses, diamond-and-platinum earrings, a bracelet or two, a couple of diamond rings the size of cherry tomatoes, and a watch covered with jewels and worth nearly a million dollars.")
} 
considered stereotype. It turns out, as a Nevada employer remarked, that "[y]ounger folks are into body art, and have a good work ethic. ${ }^{96}$

\section{Conclusion}

I have argued that we should reconceive the legality of workplace dress codes in terms of the universal protections for liberty and autonomy that are protected by the right of privacy rather than, as we have done, through group-based equality doctrine. My proposal does not require a break with past law but rather simply a shift in emphasis. That is, using the formulation of Carbado, Gulati, and Ramachandran, that appearance requirements are "a kind of forced assimilation into gender normative behavior," I simply suggest we focus more than we have on the forced assimilation part as opposed to the gender normativity part.

A casual reader of the legal literature on appearance regulation might come away with the vague impression either that people who write on the topic are especially literary in their tastes or that there is some deep connection between novels and the law of appearances. The truth of the matter is that novelists have, because of the constraints of their task, learned something that lawyers have not: appearances matter because of what they reveal about interiors. A lawyer or judge arguing that workplace appearance regulation is inoffensive or trivial operates from that old notion (especially popular with parents trying to console an adolescent insecure about his or her looks or to counsel someone making an unwise choice in love) that looks are only skin deep. A novelist would never say that; the description of a character's appearance in a novels is rarely just about the surface; it is about revelation of a character's personality, history, motivations, and future.

\footnotetext{
${ }^{66}$ Tattoos in Business, supra note
} 
So too in life. The way people choose to dress and other aspects of their appearance are deliberate choices for most people. Those who dress to blend into a Wall Street culture do so because that's how they see themselves in the world, or feel themselves in the world. Those who choose to dye their hair green do so because they want to be noticed by those without green hair (and to blend in among the green hair crowd). The way we choose to dress, and it is always an ongoing process of choice, is part of everyone's process of self-definition. Whatever someone's choice, to require him or her to dress in a way that feels fundamentally contrary to his or her preferences is to ask him or her to project an inauthentic self. Regardless of whether you can identify your self-definition with a group currently protected under antidiscrimination law, the right to define your self is at the very core of what the right of privacy should protect. 